\title{
HIDROLISIS ASAM KLORIDA TEPUNG PATI SINGKONG (Manihot esculenta Crantz) DALAM PEMBUATAN GULA CAIR
}

\author{
RTM Sutamihardja ${ }^{1)}$, Srikandi $^{2)}$, Dian Purnamasari Herdiani ${ }^{1)^{*}}$ \\ ${ }^{1)}$ Program Studi Kimia FMIPA Universitas Nusa Bangsa Bogor \\ ${ }^{2)}$ Program Studi Biologi FMIPA Universitas Nusa Bangsa Bogor \\ Jl. KH Soleh Iskandar KM 4 Cimanggu Tanah Sareal, Bogor 16166 \\ *e-mail: purnamasaridian43@gmail.com
}

\section{ABSTRACT \\ Chloride Acid Hydrolysis of Cassava (Manihot esculenta Crantz) Strach Flour in Producing a Liquid Sugar}

\begin{abstract}
Cassava (Manihot esculenta Crantz), known as cassava or manioc is a tuber or root of a tree that long with a diameter average of 5-10 cm and a length of 50-80 cm, depending on the type of cassava. Cassava is agricultural products that having high potency source of carbohydrates for food and industrial materials. Cassava starch can be made for liquid sugar by the method of acid hydrolysis using hydrochloric acid. The research results showed that rendemen at a HCl concentration of $0.75 \mathrm{~N}$ and hydrolysis time of 90 minutes was $80.51 \%$. The higest rendemen of liquid sugar at a concentration of $0.5 \mathrm{~N} \mathrm{HCl}$ and the hydrolysis time of 90 minutes was $84.22 \%$. Results of the analysis indicate liquid sugar content of $16.22 \%$ moisture, ash content of $1.46 \%, 2.16 \%$ protein content, fat content of $0.53 \%$, carbohydrates of $63.90 \%$, and a negative starch content.
\end{abstract}

Key words: Cassava, Flour Cassava Starch, Acid Hydrolysis, Liquid Sugar

\begin{abstract}
ABSTRAK
Singkong (Manihot esculenta Crantz) yang dikenal sebagai ketela pohon atau ubi kayu merupakan umbi atau akar pohon yang rata-rata berdiameter $5-10 \mathrm{~cm}$ dan panjang $50-80 \mathrm{~cm}$, tergantung dari jenis singkong. Singkong merupakan hasil produk pertanian yang potensinya tinggi sebagai sumber karbohidrat untuk bahan pangan dan industri. Pati singkong dapat dibuat gula cair dengan metode hidrolisis asam menggunakan asam klorida. Hasil penelitian menunjukkan bahwa nilai rendemen tertinggi pada konsentrasi $\mathrm{HCl} 0,75 \mathrm{~N}$ dan waktu hidrolisis 90 menit yaitu sebesar 80,51\%. Rendemen tertinggi kadar gula pereduksi dari pembuatan gula cair dengan konsentrasi $\mathrm{HCl} 0,5 \mathrm{~N}$ dan waktu hidrolisis 90 menit sebesar 84,22\%. Hasil analisa gula cair menunjukkan kandungan kadar air 16,22\%, kadar abu 1,46\%, kadar protein 2,16\%, kadar lemak 0,53\%, karbohidrat 63,90\%, dan kandungan pati negatif.
\end{abstract}

Kata kunci: Singkong, Tepung Pati Singkong, Hidrolisis Asam, Gula Cair

\section{PENDAHULUAN}

Gula merupakan salah satu kebutuhan pangan pokok dalam kehidupan sehari-hari. Gula digunakan hampir dalam semua produk pangan baik itu pada makanan ringan maupun pada berbagai jenis masakan karena gula dapat memberikan rasa manis pada produk akhir. Tahun 2012 kebutuhan gula kristal putih sebesar 5,13 juta ton, dimana 2,60 juta ton adalah kebutuhan rumah tangga dan sisanya 2,53 juta ton adalah kebutuhan industri. Sementara jumlah produksi sebesar 2,5 juta ton sehingga kekurangan kebutuhan dipenuhi melalui impor (Suripto et al, 2013). Ketergantungan pada impor diperkirakan akan terus berlangsung sejalan dengan pertambahan penduduk dan peningkatan pendapatan masyarakat serta pertumbuhan industri.

Kebutuhan gula kristal yang tinggi sedangkan gula kristal masih tergantung pada impor, maka diperlukan pemanis alternatif. Sumber alternatif pemanis non 
tebu dapat berasal dari pati yang diperoleh dari umbi-umbian untuk dijadikan gula cair, salah satunya adalah umbi kayu (singkong). Singkong sebagai sumber pati selama ini diketahui masyarakat hanya sebagai sumber karbohidrat, sampai munculnya inovasi proses yang dapat memproses singkong menjadi berbagai produk lain salah satunya gula cair.

Singkong (Manihot esculenta crantz) merupakan salah satu sumber kabohidrat lokal Indonesia. Singkong memiliki komposisi kimiawi terdiri atas kadar air sekitar $60 \%$, serat kasar $0,6 \%$, kadar karbohidrat $34 \%$, kadar protein $0,7 \%$, kadar lemak $0,2 \%$ dan kadar abu 1\% (Nuruliman, 2006). Gula cair dapat dibuat dari bahan baku yang berasal dari umbi kayu langsung maupun dari hasil pengolahannya yaitu berupa tepung.

Menurut Febriyanto (2015), gula cair dapat dibuat dari tepung pati dengan waktu hidrolisis 30 menit dan konsentrasi $\mathrm{HCl} 0,5 \mathrm{~N}$, kadar gula yang dihasilkan sebesar 40,69\%. Dalam penelitian Mayasari (2007), gula cair dapat dihasilkan dengan proses hidrolisis 60 menit. Jenis asam yang digunakan dalam penelitian ini adalah asam klorida karena memiliki daya inversi yang baik (Susmiati, 2010). Sehingga dalam penelitian ini dicari optimasi kadar gula cair dari konsentrasi $\mathrm{HCl}(0,25 \mathrm{~N}, 0,5 \mathrm{~N}, 0,75 \mathrm{~N})$ dan waktu hidrolisis (30, 60 dan 90 menit).

Menurut Suripto et al (2013), sirup glukosa atau gula cair dihasilkan dari proses hidrolisis pati oleh enzim dan hidrolisis asam, sehingga dihasilkan senyawa D-glukosa, maltosa, dan polimer D-glukosa. Gula cair yang sudah banyak beredar yaitu menggunakan hidrolisis dengan enzim.

Tujuan penelitian adalah untuk membuat gula cair dari tepung pati singkong dengan metode hidrolisis asam.

\section{BAHAN DAN METODE}

\section{Bahan}

Bahan yang digunakan dalam pembuatan glukosa cair adalah tepung pati singkong, air, $\mathrm{HCl}(0,25 \mathrm{~N}, 0,5 \mathrm{~N}$, $0,75 \mathrm{~N}$ ), arang aktif, resin anion kation, dan $\mathrm{Na}_{2} \mathrm{CO}_{3}$. Bahan yang digunakan untuk analisis parameter kimia adalah air suling, $\left(\mathrm{NH}_{4}\right)_{2} \mathrm{HPO}_{4} 10 \%$, Pb-asetat $5 \%, \mathrm{H}_{2} \mathrm{SO}_{4}$ pekat, $\mathrm{HCl} 0,1 \mathrm{~N}, \mathrm{NaOH}$ $30 \%$, Luff Schrool, KI 20\%, $\mathrm{Na}_{2} \mathrm{~S}_{2} \mathrm{O}_{3}$, dan amilum.

Alat

Alat yang digunakan dalam pembuatan glukosa cair adalah wadah penampung tepung, piala gelas, pengaduk, termometer, stopwatch, penangas air. Alat yang digunakan untuk analisis parameter kimia meliputi neraca analitik, cawan poselen, kotak timbang, desikator, oven, tanur, erlenmeyer, pipet volumetri, kertas saring, gelas ukur, labu ukur, thimble, soxhlet, penampung lemak, corong, $\mathrm{pH}$ meter kertas.

\section{Metode}

\section{Pembuatan Pati dari Singkong (Prangdimurti, 1991)}

Proses pembuatan pati dari singkong dengan cara mengupas dan membersihkan singkong dari kulitnya, kemudian singkong yang sudah bersih dan diparut. Hasil dari parutan singkong ditambahkan air secukupnya, diperas dan disaring dengan kain saring.

Hasil penyaringan didiamkan selama 8 jam untuk mengendapkan patinya. Air pada bagian atas dibuang, sedangkan endapan pati dicuci dengan air dan diendapkan lagi beberapa saat. Pati yang diperoleh selanjutnya dikeringkan menggunakan oven pada suhu $60^{\circ} \mathrm{C}$ selama 72 jam, lalu diblender dan diayak. 


\section{Pembuatan Gula Cair}

Pembuatan gula cair terdiri dari dua tahap yaitu tahap gelatinisasi dan tahap hidrolisa. Pertama-tama ditimbang 25 gram tepung pati singkong dalam erlenmeyer, lalu ditambahkan air mendidih sebanyak $75 \mathrm{~mL}$. Setelah itu dipanaskan di atas penangas dengan suhu $60-70 \quad{ }^{\circ} \mathrm{C}$ hingga terbentuk gel. Sampel ditambahkan $\mathrm{HCl}(0,25 \mathrm{~N}, 0,5 \mathrm{~N}$, $0,75 \mathrm{~N})$ sebanyak $15 \mathrm{~mL}$, lalu dimasukkan ke dalam autovlave pada suhu $121^{\circ} \mathrm{C}$ dengan tekanan 1 atm selama 30, 60 dan 90 menit.

Gula cair yang terbentuk dicek $\mathrm{pH}-$ nya dan dinetralkan, lalu ditambahkan arang aktif sebanyak 0,5 gram dan didiamkan selama satu jam kemudian disaring. Filtrat hasil penyaringan dialirkan ke dalam kolom resin anion dan kation. Sampel diuapkan di dalam evaporator pada suhu $100{ }^{\circ} \mathrm{C}$. Hasil dari evaporasi selanjutnya dilakukan pengujian untuk parameter kimia.

\section{Karakteristik Fisik Gula Cair}

Karakteristik fisik gula cair terdiri dari pengujian bau, rasa, warna dan perhitungan jumlah rendemen yang dihasilkan. Untuk pengujian bau, rasa dan warna dilakukan secara langsung dengan menggunakan indra penciuman, pengecap dan penglihatan. Sedangkan untuk perhitungan rendemen dapat diperoleh dengan rumus

Rendemen $(\%)=\frac{B s \times\left[\frac{B k}{100}\right\}}{B p \times\left(1-\frac{k a}{100}\right)} \times 100 \%$

Keterangan :

Bs : Berat glukosa cair

$\mathrm{Bk}$ : Total padatan glukosa cair

Bp : Berat pati yang digunakan

$\mathrm{Ka}$ : Kadar air glukosa cair

4. Pengujian proksimat kadar air, abu, kadar karbohidrat,protein dan lemak dan serat kasar menggunakan SNI 01-2891-1992

\section{Analisis Kadar Gula Pereduksi dengan Metode Luff Schrool (SNI 3547.2-2008)}

Sampel gula cair sebanyak 2 gram ditimbang dengan neraca analitik dan dimasukkan ke dalam labu takar 250 $\mathrm{mL}$. Sampel dilarutkan dengan air suling $50 \mathrm{~mL}$, ditambahkan $5 \mathrm{~mL} \mathrm{~Pb}$ asetat 5\%, diteteskan 1 tetes $\left(\mathrm{NH}_{4}\right)_{2} \mathrm{HPO}_{4} 10 \%$, apabila timbul endapan putih maka penambahan $\mathrm{Pb}$ asetat setengah basa sudah cukup. Larutan sampel ditambahkan $15 \mathrm{~mL}$ $\left(\mathrm{NH}_{4}\right)_{2} \mathrm{HPO}_{4} 10 \%$. Untuk menguji apakah $\mathrm{Pb}$-asetat setengah basa sudah diendapkan seluruhnya, teteskan 1-2 tetes $\left(\mathrm{NH}_{4}\right)_{2} \mathrm{HPO}_{4} 10 \%$, apabila tidak timbul endapan berarti penambahan $\left(\mathrm{NH}_{4}\right)_{2} \mathrm{HPO}_{4} \quad 10 \%$ sudah cukup. Ditepatkan dengan air suling, lalu dikocok dan didiamkan selama 30 menit hingga larutan mengendap.

Larutan sampel disaring dan dipipet $10 \mathrm{~mL}$ dimasukkan ke dalam erlenmeyer asah $250 \mathrm{~mL}$, ditambahkan $15 \mathrm{~mL}$ air suling dan 25 $\mathrm{mL}$ larutan Luff Schoorl serta beberapa butir batu didih. Dihubungkan erlenmeyer dengan pendingin tegak, panaskan di atas pemanas listrik. Dipanaskan terus selama 10 menit kemudian angkat dan segera dinginkan dalam bak berisi es. Setelah dingin tambahkan $10 \mathrm{~mL}$ larutan KI $20 \%$ dan $25 \mathrm{~mL}$ larutan $\mathrm{H}_{2} \mathrm{SO}_{4} \quad 25 \%$ (hati-hati terbentuk gas $\mathrm{CO}_{2}$ ). Dititar dengan larutan natrium tiosulfat $0,1 \mathrm{~N}$ dengan indikator larutan kanji $0,5 \%$. Dikerjakan penetapan blanko dengan $25 \mathrm{~mL}$ air dan $25 \mathrm{~mL}$ larutan Luff Schoorl seperti cara diatas. Kadar gula pereduksi diperoleh dengan menggunakan Tabel Luff Schoorl (Lampiran) dan rumus :

$$
\begin{aligned}
\mathrm{V}_{\text {koreksi }}= & \frac{\mathrm{V} \text { blanko- } \mathrm{V} \text { sampel }}{0,1} \times \mathrm{N} \text { Tío } \\
\mathrm{W}_{1}= & \mathrm{mg} \text { Tabel Luff Schoorl }+ \\
& \left(\left(\mathrm{V}_{\text {koreksi }}-\mathrm{V}_{\text {tio tabel Luff Schoorl }}\right) \mathrm{x}\right. \\
& \text { selisih })
\end{aligned}
$$


Kadar gula pereduksi $=$

$$
\frac{W 1 \times f p}{W} \times 100 \%
$$

Keterangan :

$$
\begin{array}{ll}
\mathrm{W}_{1} & \text { : mg setara } \\
\mathrm{W} & : \text { Bobot sampel } \\
\mathrm{fp} & : \text { Faktor pengenceran }
\end{array}
$$

\section{Analisis Kandungan Pati} (Kualitatif)

Pengujian kandungan pati secara kualitatif dilakukan untuk mengetahui ada atau tidaknya pati dalam contoh sehingga hasil yang didapatkan hanyalah positif atau negatif tanpa adanya besaran kadar. Pengujian dilakukan dengan cara mengambil 5-10 tetes sampel gula cair yang telah dihasilkan dari bahan baku singkong. Sampel tersebut dimasukkan ke dalam tabung reaksi, lalu ditambahkan sedikit air untuk mempermudah proses pengamatan. Kemudian ditambahkan 3-5 tetes larutan lugol ke dalam tiap tabung reaksi, amati perubahan warna yang terjadi. Bila larutan sampel menghasilkan warna biru tua atau ungu maka sampel tersebut positif mengandung pati.

\section{HASIL DAN PEMBAHASAN}

Singkong terdiri dari kulit luar berwarna coklat, kulit dalam dan umbi. Bagian daging umbi dimanfaatkan sebagai bahan pangan dan bahan baku industri sedangkan kulit luar dan kulit dalam dibuang karena selain rasanya pahit juga mengandung senyawa sianida yang bersifat toksik (Cereda dan Mattos, 1996). Singkong dapat dibuat menjadi tepung pati yang diekstrak dengan menggunakan air untuk kemudian diendapkan. Menurut Koswara (2009) rendemen yang dihasilkan dalam pembuatan tepung pati singkong sekitar $15-20 \%$, dalam penelitian ini rendemen tepung pati singkong sebesar $26,65 \%$.

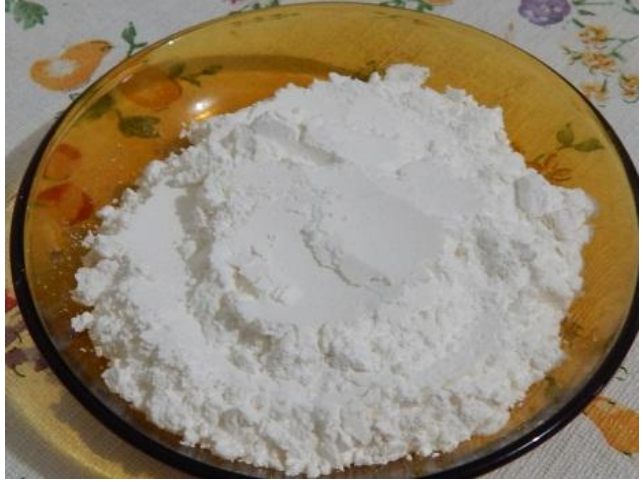

Gambar 1. Hasil Pembuatan Tepung Pati Singkong

Selanjutnya tepung pati singkong diuji kandungan proksimatnya hasilnya dibandingkan dengan SNI 3451:2011 hasilnya dapat dilihat pada Gambar 2.

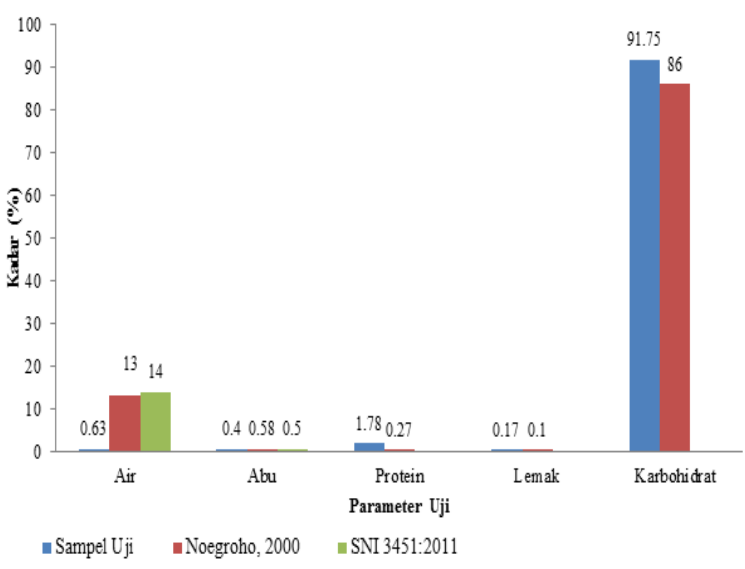

Gambar 2. Grafik Hasil Uji Kandungan Proksimat Tepung Pati Singkong

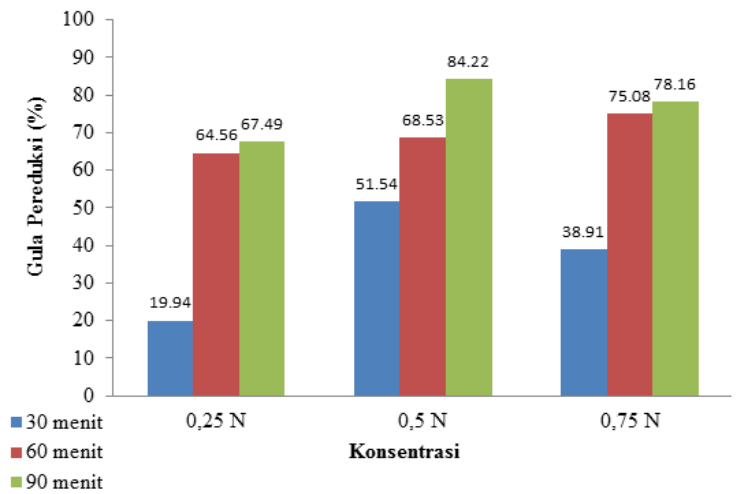

Gambar 3. Grafik Optimasi Kadar Gula Cair 
Kandungan gula pereduksi merupakan indikator pengontrol kualitas dan kuantitas suatu proses hidrolisis. Pengaruh peningkatan konsentrasi asam klorida dan waktu hidrolisis terhadap kandungan gula pereduksi dalam pembuatan gula cair dari singkong dapat dilihat pada Gambar 3.

Hasil optimasi pembuatan gula cair menunjukkan bahwa hidrolisis menggunakan asam dengan konsentasi $0,5 \mathrm{~N}$ dan waktu hidrolisis 90 menit menghasilkan kadar gula sebesar $84,22 \%$. Penurunan kadar gula pereduksi disebabkan terjadinya reaksi kebalikan dari molekul glukosa dan maltosa membentuk oligosakarida yang lebih tinggi yang bersifat non pereduksi. hasil uji dibandingan dengan gula cair di pasaran (Gambar 4).

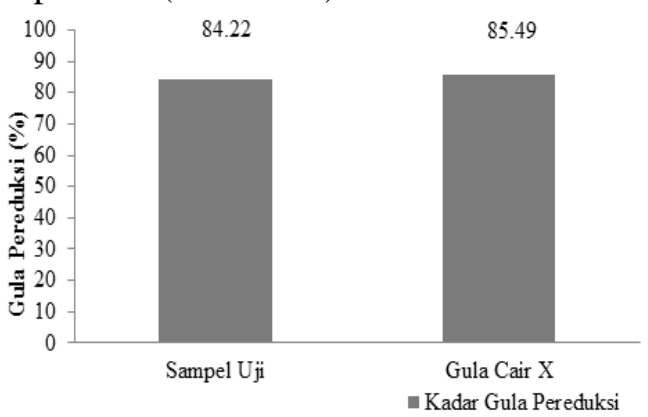

Gambar 4. Grafik Perbandingan Kadar Gula Pereduksi

Dari hasil optimasi kadar gula pereduksi sebesar $84,22 \%$ mendekati hasil kadar gula dari gula cair x yang terdapat di pasaran. Bila hasil tersebut dibandingkan dengan SNI 01-2978-1992 yang mensyaratkan batas minimum kadar glukosa dalam gula cair sebesar $30 \%$.

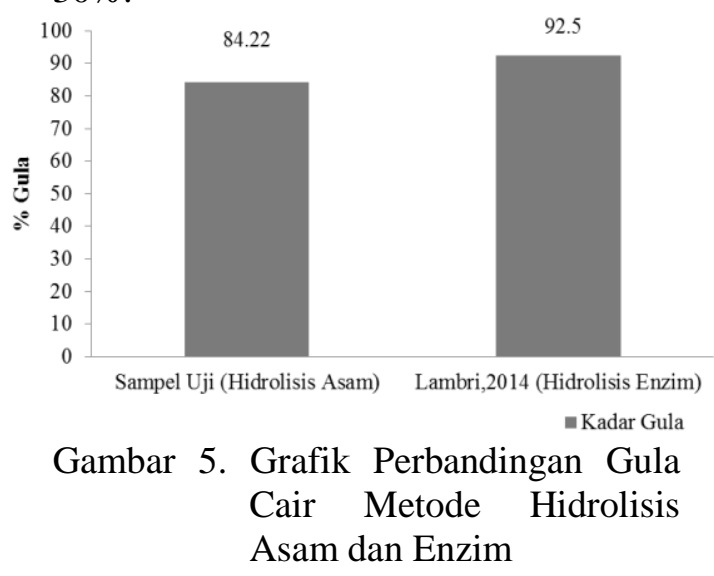

Gula cair dapat dihasilkan dari proses hidrolisis asam dan hidrolisis enzim. Enzim $\alpha$-amilase dalam menghidrolisa ikatan karbon pati menghasilkan fraksi-fraksi molekul yang terdiri atas enam sampai tujuh unit glukosa. Namun, jika waktu reaksinya diperpanjang maka komponen tersebut akan tehidrolisa menjadi campuran antara glukosa, maltosa dan maltotriosa (Parwiyanti,dkk, 2011). Kadar gula cair dengan proses hidrolisis asam dibandingkan dengan proses hidrolisis enzim, hasilnya dapat dilihat pada Gambar 5.

Tabel 1. Karakteristik Fisik Gula Cair

\begin{tabular}{|c|c|c|c|c|}
\hline \multirow{2}{*}{$\begin{array}{l}\text { Waktu } \\
\text { (detik) }\end{array}$} & \multirow{2}{*}{$\begin{array}{l}\text { Konsentrasi } \\
\text { (N) }\end{array}$} & \multicolumn{3}{|c|}{ Parameter } \\
\hline & & $\mathrm{Bau}$ & Rasa & Warna \\
\hline \multirow{3}{*}{30} & 0,25 & Khas & Manis & Kuning kecolklatan \\
\hline & 0,5 & Khas & Manis & Kuning kecoklatan \\
\hline & 0,75 & Khas & Manis & Kuning kecolklatan \\
\hline \multirow{3}{*}{60} & 0,25 & Khas & Manis & Kuning kecoklatan \\
\hline & 0,5 & Khas & Manis & Kuning kecoklatan \\
\hline & 0,75 & Khas & Manis & Kuning kecolklatan \\
\hline \multirow{3}{*}{90} & 0,25 & Khas & Manis & Kuning kecoklatan \\
\hline & 0,5 & Khas & Manis & Kuning kecolklatan \\
\hline & 0,75 & Khas & Manis & Kuning kecoklatan \\
\hline \multicolumn{2}{|c|}{ SNI 01-2978-1992 } & Tidak berbau & Manis & Tidak berwarna \\
\hline
\end{tabular}


Dari hasil perbandingan dengan metode hidrolisis menggunakan enzim, kadar gula yang didapat dengan hidrolisis enzim memiliki kadar yang besar. Proses hidrolisis secara enzimatis memiliki keunggulan bila dibandingkan dengan hidrolisis asam, yaitu pemutusan rantai polimer lebih spesifik sehingga produk yang dihasilkan sesuai dengan keinginan, dihasilkan sedikit abu dan produk samping serta kerusakan warna dapat diminimalkan.

Karakteristik fisika gula cair terdiri dari pengujian bau, rasa, warna dan perhitungan rendemen. Hasil pengamatan dapat dilihat pada Tabel 1.

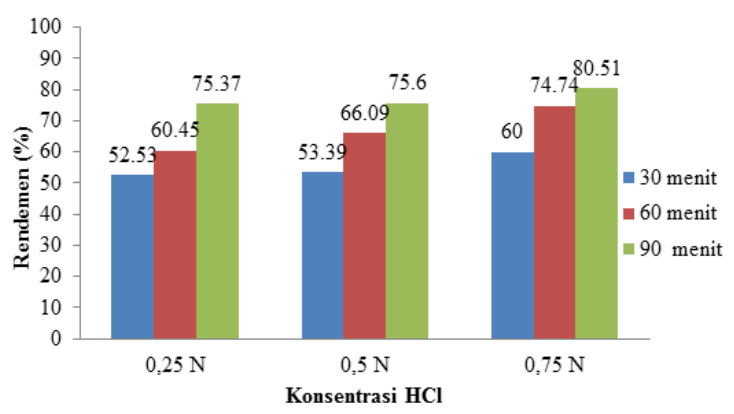

Gambar 6. Grafik Kadar Rendemen Optimasi Gula Cair

Nilai rendemen didapatkan dari hasil pembagian antara bobot glukosa cair yang dihasilkan dengan bobot bahan baku yang digunakan lalu dikalikan dengan $100 \%$. Sesuai dengan Gambar 3, hasil rendemen yang didapatkan berbeda-beda antara glukosa cair yang dihasilkan dari konsentrasi $\mathrm{HCl}$ dan waktu hidrolisis. Nilai rendemen glukosa cair dari konsentrasi $0,75 \mathrm{~N}$ dengan waktu 90 menit lebih baik. Hal ini bisa disebabkan oleh beberapa faktor baik itu dari suhu, lama pemanasan dan konsentrasi asam yang digunakan.

Pati merupakan senyawa polisakarida yang banyak terkandung di dalam tepung yang berasal dari umbiumbian. Dari hasil analisis pati secara kualitatif yang telah dilakukan terhadap glukosa cair berbahan baku tepung pati singkong didapatkan hasil negatif. Hal ini ditandai dengan tidak adanya perubahan warna pada sampel gula cair saat ditetesi larutan lugol, sehingga dapat dinyatakan bahwa bahan baku tepung pati singkong telah dihidrolisis dengan sempurna. Sampel akan menunjukan hasil positif apabila masih ada pati yang belum terhidrolisis. Hal ini dapat diamati dari perubahan warna yang terjadi, apabila terbentuk warna biru tua atau ungu maka sampel glukosa cair tersebut positif mengandung pati (Gambar 7).

Salah satu parameter yang diamati dalam penelitian ini adalah kandungan proksimat untk mengetahui kandungan nutrisi dalam gula cair. Hasil uji yang dilakukan terhadap gula cair dibandingan dengan SNI 01-2978-1992 (Gambar 8).

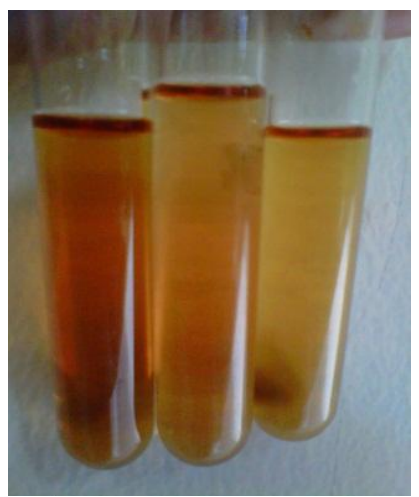

Gambar 7. Hasil Uji Kandungan Pati Pada Gula Cair

Secara umum hasil proksimat yang diujikan, didapatkan kadar yang tidak mendekati SNI, kecuali untuk kadar air. Air adalah senyawa yang dominan pada bahan pangan. Air sebagai media yang mendukung reaksi kimia, dan air secara langsung sebagai reaktan dalam proses hidrolisis. Kadar air atau kandungan air di dalam suatu bahan akan mempengaruhi mutu karena berhubungan erat dengan daya awet bahan selama penyimpanan. Dari hasil analisis kadar air, diperoleh kadar air gula cair sebesar $16.22 \%$, bila dibandingkan dengan SNI 01-2978-1992 memenuhi syarat yaitu maksimal 20\%. Semakin rendah kadar airnya maka kualitas glukosa cair 
tersebut semakin baik karena nilai viskositasnya tinggi sehingga glukosa cair akan semakin kental, selain itu kadar air yang rendah akan mengurangi bahaya pertumbuhan mikroba (Kusnadar, 2010).

Kadar abu berhubungan dengan kandungan mineral dalam bahan. Menurut Gaman dan Sherrington (1992), mineral yang terdapat dalam suatu bahan dapat berupa garam organik dan garam anorganik. Yang termasuk dalam garam organik yaitu garam-garan asam oksalat, asetat, malat, sedangkan garam anorganik antara lain garam fosfat, karbonat, klorida, sulfat dan nitrat. Kadar abu gula cair yaitu $1,46 \%$, bila hasil analisa dibandingkan terhadap SNI 01-2978-1992 maka dapat dinyatakan bahwa kadar abu gula cair dari bahan baku tepung pati singkong tidak memenuhi syarat yaitu maksimal $1 \%$. Kadar abu tidak memenuhi syarat disebabkan karena pada saat pembuatan glukosa cair dengan bahan baku tepung pati singkong, terlalu banyak penambahan $\mathrm{Na} 2 \mathrm{CO} 3$ pada saat penetralan produk.

Protein adalah sumber asam amino yang mengandung unsur-unsur $\mathrm{C}, \mathrm{H}, \mathrm{O}$ dan N. Protein berfungsi untuk membentuk jaringan baru dan mempertahankan jaringan yang telah ada. Menurut Winarno (2008), protein merupakan zat yang penting bagi tubuh manusia karena berfungsi sebagai bahan bakar dalam tubuh dan juga sebagai bahan pembangun dan pengatur. Kadar protein dari gula cair berbahan baku tepung pati singkong sebesar $2,16 \%$. Pada proses pembuatan glukosa cair hanya proses hidrolisis yang terjadi, sehingga tidak ada kemungkinan untuk naiknya kadar protein pada produk akhir.

Lemak merupakan sumber energi bagi tubuh yang lebih efektif daripada karbohidrat dan protein. Satu gram lemak menghasilkan 9 kkal energi sedangkan karbohidrat dan protein hanya menghasilkan $4 \mathrm{kkal}$. Tahap awal penggunaan lemak sebagai sumber energi adalah hidrolisis trigliserida oleh enzim lipase yang akan menghasilkan gliserol dan asam lemak. Dari hasil analisis yang telah dilakukan didapatkan hasil kadar lemak pada sampel gula cair dari tepung pati singkong $0,53 \%$. Kadar lemak yang didapatkan sangat kecil kadarnya bahkan dari bahan baku tepung tapioka tidak mengandung lemak $0,17 \%$.

Dalam ilmu gizi karbohidrat terbagi menjadi karbohidrat sederhana dan karbohidrat kompleks (Almatsier, 2001). Semakin tinggi kadar air, kadar abu, kadar protein dan kadar lemak maka semakin menurun kadar karbohidrat yang dihasilkan. Kadar karbohidrat glukosa cair sebesar $63,90 \%$. Bila diamati kadar karbohidrat dari setiap glukosa cair yang terbentuk dapat dikatakan bahwa glukosa cair ini merupakan sumber energi yang baik karena mengandung kadar karbohidrat yang cukup tinggi (Winarno, 2008).

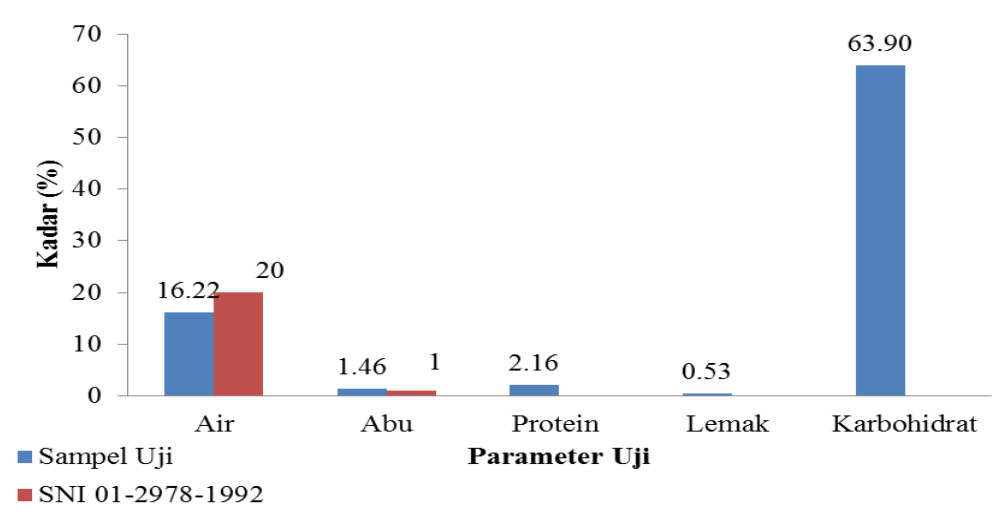

Gambar 8. Grafik Hasil Uji Kandungan Proksimat Gula Cair 
Setiap produk pangan memiliki kandungan energi yang berbeda-beda tergantung dari kadar karbohidrat, kadar protein dan kadar lemak yang terkandung di dalamnya. Energi dalam produk pangan dapat dihitung dengan rumus $(9 \mathrm{x}$ kadar lemak $)+(4 \mathrm{x}$ kadar protein $)+(4 \times$ kadar karbohidrat $)$. Hasil perhitungan dinyatakan dalam satuan kilo kalori atau kkal per 100 gram sampel. Perhitungan energi biasanya dilakukan untuk pembuatan tabel Angka Kebutuhan Gizi (AKG). Dalam industri makanan dan minuman, pencantuman kandungan energi pada kemasan dapat menambah harga jual dari produk tersebut. Kandungan energi dari glukosa cair sebesar 269,01 kkal/100 gram.

\section{KESIMPULAN DAN SARAN}

Berdasarkan hasil penelitian yang diperoleh dapat disimpulkan bahwa Gula cair dapat dibuat dari bahan baku tepung pati singkong dengan metode hidrolisis asam. Kadar gula tertinggi diperoleh pada konsentrasi $\mathrm{HCl} 0,5 \mathrm{~N}$ dan waktu hidrolisis 90 menit sebesar $84,22 \%$

Perlu dilakukan penelitian lebih lanjut terhadap metode pembuatan glukosa cair ini terutama pada proses hidrolisis enzim, analisa kandungan logam dan analisa mikroba. Perlu dilakukan penelitian pembuatan gula cair untuk menghilangkan bau khas singkong yang dihasilkan dan warna yang sesuai dengan SNI 01-2978-1992.

\section{DAFTAR PUSTAKA}

Almatsier, S. 2001. Prinsip Dasar Ilmu Gizi. Gramedia Pustaka Utama. Jakarta.

Badan Standardisasi Nasional. 1992. SNI 01-2891-1992 Cara Uji Makanan dan Minuman. Jakarta.
Badan Standardisasi Nasional. 2008. SNI 2547.2-2008 Kembang GulaBagian 2: Lunak. Jakarta.

Cereda, M.P. dan M.C.Y.Mattos. 1996. Linamarin- The Toxic Compound of Cassava.Journalof Venomous Animals and Toxins.

Febriyanto, A. 2015. Pembuatan Glukosa Cair dari Tepung Tapioka, Tepung Jagung dan Tepung Ubi Jalar dengan Metode Hidrolisis Asam. Fakultas Matematika dan Ilmu Pengetahuan Alam Universitas Pakuan. Bogor

Gaman, P.M. dan K.B.Sherrington. 1992. Ilmu Pangan, Pengantar Ilmu Pangan,

Nutrisi dan Mikrobiologi. Edisi Kedua. Gadjah Mada University Press. Yogyakarta.

Koswara, S. 2009. Teknologi Pengolahan Singkong. Departemen Ilmu dan Teknologi Pangan Fakultas Teknologi Pertanian Institut Pertanian Bogor. Bogor

Kusnandar, F. 2010. Kimia Pangan Komponen Mikro. PT Dian Rakyat. Jakarta.

Mayasari, T. 2007. Pengaruh Hidrolisa dan Konsentrasi Asam Terhadap Rendemen dan Mutu Sirup Glukosa dari Pati Pisang Kepok (Musa paradisiaca L.). Departemen Teknologi Pertanian Universitas Sumatera Utara. Sumatera Utara.

Nuruliman, A. 2006. Produksi Hidrolisat Pati dan Serat Pangan dari Singkong dengan Hidrolisis Asam Klorida. Fakultas Teknologi Pertanian Institut Pertanian Bogor. Bogor. 
Parwiyanti, Filli P., dan Renti A. 2011. Sifat Kimia dan Fisik Gula Cair dari Pati Umbi Gadung (Dioscorea hispida Denntsi). Universitas Sriwijaya. Palembang.

Sukmawati, R.F. dan Salimatul M. 2009.Pembuatan Bioetanol dari Kulit Singkong.Universitas Sebelas Maret. Surakarta.

Suripto, Ma'arif ,S dan Arkema, Y. 2013. Pengambangan Gula Cair Berbahan Baku Ubi Kayu sebagai Alternatif Gula Kristal dengan Pendekatan Sistem Inovasi.Institut Pertanian Bogor. Bogor.

Susmiati, Y. 2010. Rekayasa Proses Hidrolisis Pati dan Serat Ubi Kayu untuk Produksi Bioetanol.Institut Pertanian Bogor. Bogor.

Parwiyanti, Filli P., dan Renti A. 2011. Sifat Kimia dan Fisik Gula Cair dari Pati Umbi Gadung (Dioscorea hipsida Dennts). Fakultas Pertanian. Universitas. Universitas Sriwijaya.

Winarno, F.G. 2008.Kimia Pangan dan Gizi Edisi Terbaru. M-Brio Press. Bogor 